\title{
COMMENTS
}

\section{TOWARDS ENVIRONMENTAL ENTREPRENEURSHIP: RESTORING THE PUBLIC TRUST DOCTRINE IN NEW YORK}

\author{
MiCHAEL SETH BENN ${ }^{\dagger}$
}

\section{INTRODUCTION}

The public trust doctrine provides that government holds title to certain lands and waterways in trust for the public benefit and public use. ${ }^{1}$ While the common law doctrine varies from state to state, historically it "requires that ... trust land[s] be accessible and used for a public purpose; that [they] be put to ... uses appropriate to the resource; and, in some cases, that [they] not be sold." It does not, however, foreclose the private lease and license of public lands; rather, it requires that such lands be utilized primarily for the public benefit, and only incidentally for private benefit. ${ }^{3}$ Thus, fundamentally, the public trust doctrine incorporates a public use test.

The New York public trust doctrine, as it applies to public parkland, has nebulously defined "public benefit" and "public use" as a "park," in contrast to a "non-park," use. ${ }^{4}$ In this Comment, I argue for

\footnotetext{
${ }^{\dagger}$ B.A. 2002, Cornell University; M.A. 2004, Brown University; J.D. Candidate 2007, University of Pennsylvania Law School. I would like to thank Professor Theodore Ruger, Professor Wendell Pritchett, and Mrs. Susan Shapiro for their input during this process, as well as the Board, Senior Editors, and Associate Editors of the University of Pennsylvania Law Review for their efforts in making this piece the best it could be. I also want to thank Stephanie Hales and Ryan McCarthy for their thoughtful suggestions. Lastly, and most importantly, I would also like to thank my wife and family for their help and support. All errors are mine alone.

${ }^{1}$ See infra notes 16-17 and accompanying text (discussing early definitions of the public trust doctrine in Supreme Court cases).

${ }^{2}$ Cyane Gresham, Note, Improving Public Trust Protections of Municipal Parkland in New York, 13 Fordham ENVTL. L.J. 259, 263 (2002).

${ }^{3}$ See infra notes 31-33 and accompanying text (discussing U.S. Supreme Court holdings permitting the transfer of public lands to private parties where doing so promotes the public interest by serving a public purpose).

${ }^{4}$ See Williams v. Gallatin, 128 N.E. 121, 122 (N.Y. 1920) ("A park is a pleasure ground set apart for recreation of the public.... It need not, and should not, be a mere field or open space, but no objects, however worthy ... which have no connec-
} 
a reformulation of the public trust doctrine in New York in consonance with the historical public use test, as defined by the United States Supreme Court most recently in Kelo v. City of New London ${ }^{5}$ and New York state courts more than three decades ago in Yonkers Community Development Agency v. Morris. ${ }^{6}$ Focusing specifically on New York City parks, I argue that a reformulated public trust doctrine will permit optimal public benefit from privatization of some green spaces. This public benefit will come in the form of revitalized green spaces, previously forsaken by municipal government. Further, a reformulated public trust doctrine will limit judicial intervention in this area to the courts' traditional role of striking down transactions in which government overreaches and attempts to transfer trust lands predominantly, not incidentally, for the benefit of private third parties. ${ }^{7}$

In New York, the public trust doctrine has developed on a case-bycase basis, with decisions alternately broadening or narrowing the definition of park use and thereby allowing either more or less opportunity for private use of public lands. ${ }^{8}$ This sort of analysis not only creates uncertainty, but also fundamentally misses the point. The form of the public trust doctrine, broad or narrow, should depend on what courts will accept as a sufficient public benefit accruing from private control of lands held in public trust, not on what courts believe constitutes a park or non-park use. Thus, the doctrinal ques-

tion with park purposes, should be permitted to encroach upon it without legislative authority plainly conferred ...."); see also Friends of Van Cortlandt Park v. City of New York, 750 N.E.2d 1050, 1053 (N.Y. 2001) ("[O]ur courts have time and again reaffirmed the principle that parkland is impressed with a public trust, requiring legislative approval before it can be alienated or used for an extended period for non-park purposes." (footnote omitted)). It is difficult to predict exactly what qualifies as a park or non-park use because New York courts approach this question on a case-by-case basis, pursuant to a fact-intensive inquiry. See infra Part III (discussing the inconsistency of New York's public trust doctrine as applied to parkland); see also Gresham, supra note 2, at 300 (describing uses that the New York courts have deemed "park uses"); infra note 36 and accompanying text (providing examples of approved park uses).

${ }^{5} 125$ S. Ct. 2655 (2005); see also infra Part II (discussing the Supreme Court's definition of "public use" in its takings jurisprudence as a public purpose and a public benefit).

${ }^{6} 335$ N.E.2d 327, 330-31 (N.Y. 1975).

${ }^{7}$ See Joseph L. Sax, The Public Trust Doctrine in Natural Resource Law: Effective Judicial Intervention, 68 MICH. L. REV. 471, 495-96 (1970) (describing the courts' role as forcing the legislature to expressly transfer trust lands to private third parties where such transfers appear to subordinate the public interest). Sax argues that the courts, in forcing government to expressly authorize questionable transfers to private parties, create "an openness and visibility which is the public's principal protection against overreaching, but which is often absent in the routine political process." Id. at 496.

${ }^{8}$ See infra Part III (summarizing the evolving New York doctrine). 
tion should be how a jurisdiction's highest court and/or the United States Supreme Court define(s) public use and public benefit. ${ }^{9}$ Seen through this lens, the public trust doctrine takes its cues from the Fifth Amendment's Takings Clause.

Part I of this Comment briefly traces the origin and evolution of the public trust doctrine in the United States. This discussion serves two purposes. First, it dispels the notion that the public trust doctrine is an inherently environmentalist doctrine. One may put the doctrine to environmentalist ends, but its historical origin is rooted in government encouragement of economic development. ${ }^{10}$ Second, the discussion in Part I shows that the American public trust doctrine, as initially enunciated by the U.S. Supreme Court, incorporates the public use test.

Part II examines the Supreme Court's recent decision in Kelo and discusses its implications for reformulating New York's public trust doctrine with respect to parkland. Kelo's condoning of private-toprivate takings turns on a cementing of the definition of "public use" as public purpose or benefit; this test coincides with the public use doctrine as developed by New York state courts three decades earlier in Morris. ${ }^{11}$ While it creates a dilemma for private property rights ad-

\footnotetext{
${ }^{9}$ On such a state law issue, the highest state court is, of course, authoritative in the state. Holdings of the U.S. Supreme Court, though not binding under federalism principles, are nonetheless highly persuasive. In Shivley v. Bowlby, the Supreme Court held that the individual states have the authority to define the scope of the public trust doctrine as it applies within each state. See Shivley v. Bowlby, 152 U.S. 1, 26 (1894) (" $[\mathrm{T}]$ here is no universal and uniform law upon the subject; but... each State has dealt with the lands ... within its borders according to its own views of justice and policy ....”); see also Phillips Petroleum Co. v. Mississippi, 484 U.S. 469, 475 (1988) ("[I]t has been long established that the individual States have the authority to define the limits of the lands held in public trust and to recognize private rights in such lands as they see fit."); Geoffrey R. Scott, The Expanding Public Trust Doctrine: A Warning to Environmentalists and Policy Makers, 10 FORDHAM ENVTL. L.J. 1, 23 (1998) ("The actual contemporary definition of the public trust varies from state to state and the only certain observation that might be made about the doctrine is that there is no single or uniform, [sic] explanation or application.").

${ }^{10}$ See Molly Selvin, This Tender and Delicate Business: The Public Trust DOCTRINe IN AMERICAN LAW AND ECONOMIC POLICY 1789-1920, at 11-12 (Harold Hyman \& Stuart Bruchey eds., American Legal and Constitutional History: A Garland Series of Outstanding Dissertations, 1987) (framing the evolution of the public trust doctrine in nineteenth- and early-twentieth-century American history "as part of th[e] effort toward promotion and regulation of economic development by government through the legal system").

${ }^{11}$ See Morris, 335 N.E.2d at 330-31 (holding that the City of Yonkers's taking of private property to expand an Otis Elevator Company plant was for a public purpose because "economic underdevelopment and stagnation are also threats to the public suffi-
} 
vocates in the takings context, the broadened definition of public use is a practical test in the public trust context. It permits measured private development of public property for the benefit of the public, without hindering judicial authority to void, pursuant to the public trust doctrine, transfers made primarily for the benefit of private parties. In other words, the exception does not swallow the rule.

Part III reviews the major New York cases to show that the current doctrine is unworkable and concludes that a doctrinal move from park use to public use is necessary. A special focus is the Appellate Division's 2002 ruling in SFX Entertainment, Inc. v. City of New York, ${ }^{12}$ which affirmed the decision of the New York Supreme Court (the trial court in that state) but rejected its reasoning. $S F X$ is the latest in a line of New York cases alternately expanding and narrowing the definition of park/non-park use. This jurisprudential tension arises because the New York courts rely on the notion of park use rather than public use in framing the public trust doctrine. While puzzling under the park/non-park formulation, the outcome in SFX makes sense in light of the public use test.

Part IV examines some of the effects of reformulating, under the cover of Kelo, Morris, and the public use test, the public trust doctrine as applied to parkland in New York. While some might view such a move as the harbinger of a disastrous environmental scenario, equating economic development with public use need not sacrifice environmental aspirations. Thus, Part IV argues for a more systematic focus on long-term licensing and development of underutilized New York City parkland by private entrepreneurs in close partnership with the Department of Parks and Recreation, and with an emphasis on maximizing potential public enjoyment derived from the City's green spaces. While this reformulation of the public trust doctrine may appear to have very little to do with the environmental goals some view as traditionally associated with the doctrine, ${ }^{13}$ its implementation in

cient to make their removal cognizable as a public purpose"); see also David C. Wilkes \& John D. Cavallaro, This Land is Your Land? Eminent Domain's Public Use Limitation, N.Y. ST. B.J., Oct. 2005, at 10, 14, 16 (arguing that the decision in Kelo does nothing more than reaffirm federal precedent and depicting the similarities between the federal and New York State public use tests).

${ }^{12} 747$ N.Y.S.2d 91, 92 (App. Div. 2002).

${ }^{13}$ Only since the mid-twentieth century has the doctrine's focus shifted away from economic development and towards an environmentalist agenda. See SELVIN, supra note 10, at 5-10 (recounting the doctrine's role as a tool in nineteenth- and early-twentiethcentury American economic development and describing its evolution into a means 
New York will allow for privatization and optimal public use of our parkland in environmentally and economically sound ways.

\section{DOCTRINAL ORIGINS}

The public trust doctrine's origins show that it is not innately environmentalist. Further, early statements of the doctrine in American jurisprudence connect it with the public use test, thereby supporting the thesis that the public use test should be the rule with respect to the validity of a government's lease or license of public land to private parties.

Scholars trace the origin of the public trust doctrine to Roman civil law and English common law. ${ }^{14}$ The United States inherited the public trust doctrine from Great Britain. Before the American Revolution, the navigable waterways and lands underneath them belonged to the King, in trust for the people, to ensure unimpeded access for navigation and commerce. ${ }^{15}$ After the Revolution, ownership of such property vested in the American people as a whole, ${ }^{16}$ with each State holding title to such property within its borders in public trust. ${ }^{17}$

for upholding environmental legislation enacted to curb pollution and the destruction of natural resources).

${ }^{14}$ See id. at 17-25 (reviewing antecedents to the public trust doctrine in Roman civil law and English common law). Roman civil law included the notion of res communes, which covered items such as "the air, the oceans, the sea-shore, running water and ocean fish" that were "incapable of private ownership" and "open to the free use of all," and the notion of res publicae, which covered such items as "public roads, harbors, rivers and riverbanks" that "were considered to be the property of the Roman people" and "were held for the free use of all." Id. at 17. In contrast, at English common law, the King "had dominion over these resources," but "the public had uninterrupted and inalienable rights of use and passage in them." Id. at 25. Such public rights were known as jus publicum. Id.

${ }^{15}$ See Shivley v. Bowlby, 152 U.S. 1, 57 (1893) ("At common law, the title and the dominion in lands flowed by the tide were in the King for the benefit of the nation."); Ill. Cent. R.R. Co. v. Illinois, 146 U.S. 387, 457 (1892) ("[P] rior to the Revolution, the shore and lands under water of the navigable streams ... belonged to the King of Great Britain ... and devolved to the State[s] by right of conquest.").

${ }^{16}$ See Shivley, 152 U.S. at 57 ("Upon the American Revolution, [the title and dominion in lands flowed by the tide], charged with a like trust, were vested in the original States within their respective borders, subject to the rights surrendered by the Constitution to the United States."); Martin v. Lessee of Waddell, 41 U.S. 367, 410 (1842) ("[W]hen the Revolution took place, the people of each state became themselves sovereign; and in that character hold the absolute right to all their navigable waters and the soils under them for their own common use, subject only to the rights since surrendered by the Constitution ....").

${ }^{17}$ The U.S. Supreme Court observed that the title is 
The public trust doctrine is not inherently tied to environmentalist goals, ${ }^{18}$ even though such goals may be consonant with the goal of managing public property for the public benefit. Rather, as one scholar has noted, "[ $\mathrm{t}]$ he longer the doctrine is exposed to the light of analysis, the more it becomes clear that the term is truly political/legal in content, and philosophical/social in context." ${ }^{19}$ As such, the doc-

different in character from that which the State holds in lands intended for sale. . . It is a title held in trust for the people of the State that they may enjoy the navigation of the waters, carry on commerce over them, and have liberty of fishing therein freed from the obstruction or interference of private parties.

Ill. Cent. R.R. Co., 146 U.S. at 452.

${ }^{18}$ The starting point for understanding any argument for reformulation of the public trust doctrine as it applies to parkland in New York City is to dispel the modern myth that the public trust doctrine is an environmentalist doctrine. Many scholars have been unable to avoid this claim in some form. See JACK H. ARCHER ET AL., THE PUblic TRUST DOCTRINE AND THE MANAGEMENT OF AMERICA's COASTS 1-5 (1994) (arguing that the public trust doctrine has unique potential vis-à-vis preserving America's coastal areas); JOHN CRONIN \& ROBERT F. KENNEDY, JR., THE RIVERKEEPERS: TWO ACTIVISTS FigHT TO RECLAIM OUR ENVIRONMENT AS A BASIC HUMAN RIGHT 145 (1997) (" $[\mathrm{C}]$ ourts and Congress began to breathe life into the moribund Public Trust Doctrine, raising it up in a new iteration: modern environmental law.”); Joseph L. Sax, Liberating the Public Trust Doctrine from Its Historical Shackles, 14 U.C. DAVIS L. REv. 185, 188, 193 (1980) (suggesting that "[ $\mathrm{t}]$ he central idea" of the public trust doctrine is to prevent destabilizing public expectations as related to land use, "whether the expectations are those ... of a diffuse public benefit from ecosystem protection or of a community's water supply"); see also Scott, supra note 9, at 3 ("The public trust doctrine has been heralded by environmental activists as a valuable weapon in the fight to preserve the earth's resources in a natural state and to make their enjoyment more readily accessible to the populus at large."). Yet Scott discerns that the public trust doctrine is a product of the sociopolitical environment; thus, in its environmentalist form it is "vulnerable to the same political forces through which [that form initially] found expression." Id. at 70. As such, the doctrine is constantly open to new interpretation and application. Further, the position that the public trust doctrine is innately environmentalist misses the point that the doctrine is designed to protect resources for the public benefit. One commentator explained that

[t] he public trust doctrine does not exist to allow judges to act as roving am-

bassadors on behalf of a "public" consisting mainly of environmentalists.

Rather, the doctrine protects the resources themselves. To be sure, applica-

tion of the public trust doctrine may prohibit development of a resource by a single private commercial entity, but that result allows the resource to remain open for use by a much wider range of interests-commercial and noncommercial.

Charles F. Wilkinson, The Public Trust Doctrine in Public Land Law, 14 U.C. DAVIS L. ReV. 269, 315-16 (1980).

${ }^{19}$ Scott, supra note 9, at 23. Contra CRONIN \& KENNEDY, supra note 18, at 145 (arguing that recently enacted environmental statutes, including " $[\mathrm{t}]$ he Clean Water Act, the Clean Air Act, the Endangered Species Act, and the National Environmental Policy Act [,] are all best understood as a modern guarantee of the protection of ancient public trust rights in an industrial age"). 
trine evolves over time. ${ }^{20}$ Thus, while in recent years the doctrine has been a valuable tool for environmentalists and conservationists, nothing innate to the doctrine demands that it continue to be so used. ${ }^{21}$

For much of its early existence in the United States, spanning the nineteenth and early twentieth centuries, the doctrine was the government's tool to "encourage and direct economic growth." "2 It "became a viable means for judicial allocation of valuable resources," and it was not considered odd for a court to find that "[t]he "public good" might often best be served by the private development of trust property-by perhaps a railroad or pipeline company-even if that development disrupted the traditional public uses of the property." ${ }^{23} \mathrm{Im}$ plicit in such an interpretation of the doctrine is the notion that the public benefit or public purpose ${ }^{24}$ justifying use of trust lands may be equatable to economic development primarily for the public good.

Permutations of the public trust doctrine vary from state to state. ${ }^{25}$ As they have evolved over time, American versions of the doctrine generally pigeonhole land and bodies of water into two categories of property: "(1) that which is capable of transfer, in usual and ordinary course, to private ownership; and (2) that which is not and is to be

${ }^{20}$ See Wilkinson, supra note 18 , at 280-84, which describes three stages of the doctrine's evolution. During the first era, beginning in the mid-nineteenth century and continuing until approximately 1888 , the federal government was "merely a temporary custodian and trustee," charged with the trust duty "to sell off the lands for the common benefit so that new states ... could operate as sovereigns on an equal footing with the original states ...." Id. at 280. During the second era, from 1888 to approximately 1970, "[a] consensus developed that those particular lands and resources should not be subject to random disposal but rather should be protected and managed by the United States for future generations." Id. Finally, during the third era, beginning in 1970 , individuals began applying the public trust doctrine "to limit federal power and to justify rights of the public against the federal government." Id. at 284.

${ }^{21}$ See supra note 18 and accompanying text (rehearsing the scholarly debate between those who believe the public trust doctrine is innately environmentalist and those who believe its purpose evolves depending on the sociopolitical climate).

${ }^{22}$ SELVIN, supra note 10 , at 11.

${ }^{23} I d$. at 5,149 . As such, the period is littered with examples of cases in which the courts "validated extraordinary legislative grants of privilege to semi-public corporations, most specifically the railroads and turnpike companies." Id. at 123 . The courts in effect determined that "the operation of railroads and turnpikes on city streets ... was consistent with the public trust under which the state legislatures and municipal corporations held those properties." Id.

${ }^{24}$ See infra Part II (proposing that one should view the concepts of public use and public benefit as synonymous).

${ }^{25}$ See Shivley v. Bowlby, 152 U.S. 1, 26 (1893) ("[T]here is no universal and uniform law upon the subject; but... each State has dealt with the lands under the tide waters within its borders according to its own views of justice and policy ....”). 
held by government in a public trust for its constituents." ${ }^{26}$ Historically, in America, the doctrine has focused on government ownership of waterways in fee simple. ${ }^{27}$ Some states, however, including New York, have expanded the doctrine to include other "public resource[s] in which the community has a special interest." ${ }^{28}$ For example, different variations of the doctrine encompass submerged lands ${ }^{29}$ and public parks. ${ }^{30}$

The federal rule, as set forth by the U.S. Supreme Court in Illinois Central Railroad Co. v. Illinois, ${ }^{31}$ permits the transfer of trust lands only under very specific circumstances. The Court held that "control of the State for the purposes of the trust can never be lost, except as to such parcels as are used in promoting the interests of the public therein, or can be disposed of without any substantial impairment of the public interest in the lands and waters remaining." ${ }^{32}$ Only under these cir-

${ }^{26}$ Scott, supra note 9 , at 15.

27 See supra note 15; see also Wilkinson, supra note 18, at 305-06 (analyzing the application of the public trust doctrine to federal inlands and determining that, while some aspects of the doctrine as it applies to waterways do not apply with respect to federal inlands, other aspects do).

${ }^{28}$ Scott, supra note 9 , at 19.

29 See Ill. Cent. R.R. Co. v. Illinois, 146 U.S. 387, 453 (1892) (holding that granting almost all of the submerged lands in Chicago's harbor to a railroad company was voidable because such a grant "has never been adjudged to be within the legislative power").

${ }^{30}$ See, e.g., infra Part III (discussing the public trust doctrine as it applies to parks in New York); see also Douglass v. City Council of Montgomery, 24 So. 745, 746 (Ala. 1898) (finding that the city council could not alienate parkland held in public trust for the purpose of allowing a railroad to lay tracks); Big Sur Props. v. Mott, 132 Cal. Rptr. 835, 838 (Cal. Ct. App. 1976) (holding that where property is acquired through private dedication as a public park, "it is without the power of a municipality to divert or withdraw the land from use for park purposes" (quoting Slavich v. Hamilton, 257 P. 60, 61 (Cal. 1927))).

${ }^{31} 146$ U.S. 387 (1892). See Sax, supra note 7, at 489-91 (summarizing succinctly this confusing Supreme Court opinion).

${ }^{32}$ Ill. Cent. R.R. Co., 146 U.S. at 453 (emphasis added). Joseph Sax, however, suggests that the doctrinal exception is not merely a public use test as in the takings context, but rather argues that the case law implies three limitations on a government's authority to transfer trust lands: first, trust property "must not only be used for a public purpose," but also "must be held available for use by the general public"; second, "the property may not be sold, even for a fair cash equivalent"; and third, the property must be put only to "particular types of uses." Sax, supra note 7, at 477. In support of his view as the correct articulation of the doctrine's scope, Sax urges that "[c] onfusion has arisen from the failure of many courts to distinguish between the government's general obligation to act for the public benefit, and the special, and more demanding, obligation which it may have as a trustee of certain public resources." Id. at 478 . Such a reading, however, contradicts the above-quoted language used by the U.S. Supreme Court in Illinois Central Railroad to describe when government may transfer trust lands 
cumstances may the legislature alienate trust-protected property. Similarly, state courts, including those in New York, have held that government may transfer public trust property "so long as the grantee will place it into public service by executing a trust purpose through private initiative." ${ }^{33}$

Thus, to determine whether property owned by a state is alienable, courts must apply a two-step analysis. First, courts must determine whether such property is protected by the public trust doctrine. Historically, trust-protected lands and bodies of water were those linked to navigational and commercial purposes. ${ }^{34}$ In modern times, the reasons for subjecting property to the doctrine have been expanded to include "forms of pure avocational activity." "35 In New York, for example, public parkland may be leased or (under modern case law) licensed to private parties for the purpose of conducting dances, concerts, and theater; constructing monuments and statues; and building and operating restaurants and food facilities, parking lots, zoos, gardens, and concessions. ${ }^{36}$ Second, if the doctrine protects the property in question, courts must determine whether the private party

to private parties. Further, Sax admits that support for his three-pronged formulation of the doctrine's scope comes mainly from dicta and that "the case law has not developed in any way that permits confident assertions about the outer limits of state power." Id. at 486 .

${ }^{33}$ Scott, supra note 9, at 22. The New York courts, beginning with the Court of Appeals in Williams v. Gallatin, have drawn a very fine, often shifting, line with respect to whether a stated purpose sufficiently facilitates the "public means of pleasure, recreation, and amusement, and thus provide[s] for the welfare of the community," 128 N.E. 121, 123 (N.Y. 1920), such that the transfer of the right to use parkland to a private party is valid. Where, however, the Parks Commissioner attempts to transfer the right to use property to a private person or corporation and the transferee's purpose in gaining control of the parkland does not sufficiently implicate a park-appropriate purpose, legislative approval is necessary or the courts will void the transfer. Id. at 122; see also Gresham, supra note 2, at 268 ("New York courts have a long tradition of extending public trust protections to municipal parks by requiring specific state legislative authorization for sale, alienations, or non-park uses of the land." (footnotes omitted)).

See, e.g., Barney v. City of Keokuk, 94 U.S. 324, 338 (1876) (“[T]he public authorities ought to have entire control of the great passageways of commerce and navigation, to be exercised for the public advantage and convenience."); see also Phillips Petroleum Co. v. Mississippi, 484 U.S. 469, 488 (1988) (O'Connor, J., dissenting) (opining that "the fundamental purpose of the public trust is to protect commerce").

${ }^{35}$ Scott, supra note 9 , at 20.

${ }^{36}$ See Gresham, supra note 2, at 300 (categorizing park and non-park uses of parkland in New York). 
will use such property for a trust purpose benefiting the public. ${ }^{37}$ This second step effectively incorporates the public use test prevalent in takings analysis into the public trust doctrine. ${ }^{38}$

\section{The Promise of the Kelo Dilemma in the Public Trust ConteXt}

The historical public trust doctrine incorporates the public use test developed in takings jurisprudence, whereby government may transfer trust lands to private parties for the public benefit. ${ }^{39}$ Thus, to determine what the appropriate scope of the public trust doctrine in New York should be with respect to protecting parkland, it is first necessary to understand the scope of the public use test as developed by New York state courts and the U.S. Supreme Court.

The Fifth Amendment's Takings Clause, ${ }^{40}$ which applies to the states through the Fourteenth Amendment, ${ }^{41}$ creates a two-step analysis that courts must apply to determine if government can take private real property. The first step is to determine whether government takes the private realty for a public use, while the second step is to ensure that the government provides just compensation. ${ }^{42}$ The public use element is a disabling restraint. ${ }^{43}$ If it is not fulfilled, then the analysis ends, and presumably the government's sole option is to negotiate with the private landowner for her property.

${ }^{37}$ See supra note 32 and accompanying text (suggesting that the U.S. Supreme Court has established the public use test as the exception to public trust doctrine protections).

${ }^{38}$ See infra Part II (describing the public use doctrine).

${ }^{39}$ See supra notes 32-33 and accompanying text (explaining that a government may transfer public trust property to private individuals only where such transfer serves the public interest).

${ }^{40}$ U.S. CONST. amend. V (providing in part that no "private property [shall] be taken for public use, without just compensation").

${ }^{41}$ U.S. CONST. amend. XIV, $\$ 1$ (providing that no state shall "deprive any person of . . property, without due process of law”); Chicago, Burlington \& Quincy R.R. Co. v. City of Chicago, 166 U.S. 226, 239 (1897) (applying the Fifth Amendment Takings Clause to the states by means of the Fourteenth Amendment); see also Tahoe-Sierra Pres. Council, Inc. v. Tahoe Reg'l Planning Agency, 535 U.S. 302, 306 n.1 (2002) (“Often referred to as the 'Just Compensation Clause,' the final Clause of the Fifth Amendment . . . applies to the States as well as the Federal Government.").

${ }^{42}$ See Brown v. Legal Found. of Wash., 538 U.S. 216, 231-32 (2003) (“[T] he taking must be for a 'public use' and 'just compensation' must be paid to the owner.”).

${ }^{43}$ See Kelo v. City of New London, 125 S. Ct. 2655, 2672 (2005) (O'Connor, J., dissenting) ("The public use requirement ... imposes a more basic limitation, circumscribing the very scope of the eminent domain power: Government may compel an individual to forfeit her property for the public's use, but not for the benefit of another private person."). 
The U.S. Supreme Court recently revisited the public use question in Kelo v. City of New London, and, in doing so, the Court cemented the redefinition of "public use" as for a public purpose and public benefit. ${ }^{44}$ This decision, it seems, authorizes future private-to-private transfers, by means of the takings power, in the name of economic development. In Kelo, the New London City Council authorized the New London Development Corporation (NLDC), "a private nonprofit entity established... to assist the City in planning economic development," "to purchase property or to acquire property by exercising eminent domain in the City's name." ${ }^{45}$ The petitioners, private landowners who refused to sell to the NLDC, commenced suit claiming "the taking of their properties would violate the 'public use' restriction in the Fifth Amendment." ${ }^{46}$ Thus, the issue before the Court was "whether a city's decision to take property for the purpose of economic development satisfies the 'public use' requirement of the Fifth Amendment." ${ }^{47}$

The Kelo Court held that such economic development takings are constitutional under the Fifth Amendment because they "unques-

\footnotetext{
${ }^{44}$ See id. at 2663-64 (reasoning that the public benefit of a proposed economic development plan is analogous to other public purposes previously approved by the Court). The move in this direction had been foreshadowed in earlier Supreme Court cases. In Berman v. Parker, a unanimous Court upheld a redevelopment plan invoking eminent domain and targeting a blighted area in Washington, D.C., reasoning that "[t]he concept of the public welfare is broad and inclusive," and "[i]t is within the power of the legislature to determine that the community should be beautiful as well as healthy, spacious as well as clean, well-balanced as well as carefully patrolled." 348 U.S. 26, 33 (1954). The Court also opened the door to the accomplishment of public purposes by means of private enterprise when it stated that "[w]e cannot say that public ownership is the sole method of promoting the public purposes of community redevelopment projects." Id. at 34. Similarly, in Hawaii Housing Authority v. Midkiff, the Court held that the takings power could be used by the government to establish the Land Reform Act of 1967, which reduced the concentration of land ownership for the public purpose of eliminating "the perceived social and economic evils of a land oligopoly." 467 U.S. 229, 241-42 (1984). In condoning the Hawaiian law, the Court reasoned that "it is only the taking's purpose, and not its mechanics," that determines whether a public use exists, and further stated that the Court had "long ago rejected any literal requirement that condemned property be put into use for the general public." Id. at 244; see also Wilkes \& Cavallaro, supra note 11, at 12-14 (discussing how Kelo adheres to U.S. Supreme Court precedent "that long ago established an expansive definition of the Public Use Clause"); $c f$. Yonkers Cmty. Dev. Agency v. Morris, 335 N.E.2d 327, 331 (N.Y. 1975) (reasoning that just because "the vehicle for renewed use of the land ... may be a private agency" does not mean the taking is not permissible if it serves a public purpose).

${ }^{45}$ Kelo, 125 S. Ct. at 2660.

${ }^{46} \mathrm{Id}$.

${ }^{47} I d$. at 2661 .
} 
tionably serve[] a public purpose." ${ }^{48}$ Specifically, the Court found that the proposed economic development plan has a reasonable chance of producing "new jobs and increased tax revenue." ${ }^{49}$ The Court equated the public benefits of the City's plan to those benefits reasonably accruing from approved takings in prior cases. ${ }^{50}$

While Kelo was the first U.S. Supreme Court case to deal explicitly with economic development takings, the New York courts resolved this issue more than thirty years ago. In Yonkers Community Development Agency $v$. Morris, private landowners and business owners within the City of Yonkers claimed the City took their property "for a private purpose, [namely], the expansion of the current plant facilities of the Otis Elevator Company." ${ }^{51}$ The New York Court of Appeals, the state's highest court, held that a taking for the expansion of the Otis Elevator Company was for a public purpose, reasoning that "economic underdevelopment and stagnation are also threats to the public sufficient to make their removal cognizable as a public purpose." ${ }^{52}$ The Morris court seems to identify two public benefits justifying the taking: first, where "land is found to be substandard, its taking for urban renewal is for a public purpose, just as it would be if it were taken for a public park, public school or public street"; ${ }^{53}$ second, a public benefit exists "in assuring the retention of Otis as an increased source of employment opportunity in Yonkers." ${ }^{54}$ Moreover, the court was not worried by the fact that a private benefit might accrue to Otis, so long as "the public purpose was dominant. ${ }^{, 55}$

While cases like Kelo and Morris are problematic for private property rights advocates in the takings context, they actually can provide a twofold potential benefit in the public trust context. First, application

${ }^{48} I d$. at 2665 .

${ }^{49} I d$.

${ }^{50} I d$. ("It would be incongruous to hold that the City's interest in the economic benefits to be derived from the development of the Fort Trumbull area has less of a public character than any of those other interests [arising in the context of other takings previously approved by the Court].”).

335 N.E.2d 327, 330 (N.Y. 1975).

${ }^{52} I d$.

${ }^{53} I d$. at 331 .

${ }^{54} I d$.

${ }^{55}$ Id. In the thirty-plus years since Morris, the New York state courts have developed an expansive "dominant public purpose-incidental private benefit standard," which leaves condemnees "little room ... to argue that a public purpose is not being served." Wilkes \& Cavallaro, supra note 11, at 16. The New York rule, however, would seemingly void any taking actions effectuated primarily for the benefit of a private party. 
of the public use test, as developed by the United States Supreme Court and the New York state courts, can clarify the scope of the public trust doctrine as applied to municipal parks in New York and elsewhere. Rather than focusing on the fuzzy distinction between park use and non-park use, ${ }^{56}$ the doctrine should aim at deciphering whether a public benefit accrues as a result of a municipal license or lease of parkland. ${ }^{57}$

Second, application of the public use doctrine in the public trust context can provide greater opportunity for private entrepreneurship and optimal public use of parkland. The public use test, which appears dangerously broad in the takings context, may actually do a good job of encouraging private investment in public land. As defined by the federal and New York courts, the public use test incorporated into the public trust doctrine will be broad enough to permit optimal development of public parkland for the benefit of all citizens and narrow enough to ensure that the courts will void licenses or leases of public land producing predominantly private benefits. Arguably, this is exactly as it should be. ${ }^{58}$

${ }^{56}$ See infra Part III (noting confusion in the New York doctrine as currently constituted and arguing that clarity is attainable by means of applying the public use test in the public trust context).

${ }^{57}$ While the question of what constitutes a public use or benefit is itself less than perfectly clear, it is nonetheless a question courts must answer within specifically drawn boundaries. In contrast, the decision as to whether some use is a park or non-park use seems wholly whimsical. Though some might argue that the public use test is also wholly whimsical, the fact remains that the U.S. Supreme Court has been largely consistent in delineating categories of public uses and subsequently applying them in new cases. See supra note 44 (summarizing Supreme Court cases that define public use). The New York courts, however, in applying the park use test often reach different conclusions based on similar, if not identical, facts. See infra Part III (recounting how different New York courts have reached vastly different conclusions regarding what is a park use based on the same facts, first in Friends of Van Cortlandt Park v. City of New York, 750 N.E.2d 1050 (N.Y. 2001), and subsequently in SFX Entertainment, Inc. v. City of New York, 747 N.Y.S.2d 91 (App. Div. 2002)). This is not to suggest that the public use test is perfectly clear. Indeed, it is less than perfectly clear. It seems, however, that less than perfectly clear is much better than wholly whimsical.

${ }^{58}$ This result appears correct on policy grounds because the public trust doctrine, as applied to public parkland, is designed to ensure that the public interest in such lands is protected. Where government attempts to transfer public land to private individuals merely for their private interests, the public interest is not only subordinated, but also defeated. The courts would not uphold such a transfer unless it were expressly sanctioned by the legislature. If, however, the public-to-private transfer serves the public interest, whether by means of license, lease, or alienation approved by the legislature, the courts should not disturb the judgment of the governmental body charged with managing the parkland for the public. 
Some might argue that such a doctrinal shift will have negative environmental implications as public lands are pillaged by private industry under the Kelo/Morris framework. Courts, the argument goes, will apply this broadened definition of "public use" and narrow the public trust doctrine's environmental protections by expanding the public use test to permit the unbridled transfer of trust property. In other words, there will be too much judicial discretion, leading to an environmentally unfriendly result. Thus, those government entities charged with managing public trust lands will attempt, and the courts will permit, more public-to-private transfers without legislative approval.

The problem with this counterargument is that judicial discretion is inherent in the common law public trust doctrine. This argument does not so much critique judicial discretion itself, but rather objects to how courts would be wielding that discretion, in light of the public trust doctrine's recent ties to environmentalist aims. Yet the public trust doctrine, as Geoffrey Scott points out, is not a "universal truth"; rather, it is a social construct, the product "of the varying ambitions and philosophies of the elemental constituents" of society at a particular moment in time. ${ }^{59}$ The doctrine's primary purpose is to ensure that trust property is utilized for the public benefit. ${ }^{60}$ The sociopolitical coming of age of the late $1960 \mathrm{~s}^{61}$ led certain scholars to equate the public trust doctrine with environmentalist aims. ${ }^{62}$ Nothing, however,

\footnotetext{
${ }^{59}$ Scott, supra note 9, at 7 (discussing the doctrine as a social phenomenon, subject to debate and to change with the times). Scott argues that, while environmentalists often "celebrate their victories" realized by means of the public trust doctrine "as though they have liberated universal truths," they "fail to consider that . . . the reconstitution of the public trust doctrine may be vulnerable to the same political forces through which it found expression." Id. at 70. Ultimately, for Scott, the public trust doctrine evolves as society evolves and "may not merely be the invocation of a manifest and sterile set of rules." Id. at 7 .

${ }^{60}$ See Wilkinson, supra note 18, at 315-16 (addressing recent misunderstandings of the public trust doctrine's purpose and defining such purpose as the protection of resources for the public benefit).

${ }^{61}$ See ARCHER ET AL., supra note 18, at 1 (recognizing an awakening of environmental consciousness among the American public in the late 1960s).

${ }^{62}$ See Gresham, supra note 2, at 315-19 (proposing new regulatory and legislative safeguards to ensure that the public trust doctrine will continue to be a tool for environmentalists as they seek to protect New York City's parks); see also JOHN G. SPRANKLING, UNDERSTANDING PROPERTY LAW 500 (2000) ("The public trust doctrine is one of the most far-reaching and controversial rules defining the legal relationship between private owners and the environment." (emphasis omitted)); supra note 18 (summarizing some of the scholarly views equating the public trust doctrine with environmentalist ideals). Contra Wilkinson, supra note 18, at 315-16 (arguing that the public trust
} 
exists to prevent, de facto, the doctrine's scope from shifting again in the future. ${ }^{63}$

Further, it may just be that private entrepreneurs, operating under a reformulated public trust doctrine, can produce greater public benefit from managing trust lands than government. ${ }^{64}$ The production of optimal public benefit, environmental ideals, and incidental private benefit need not be mutually exclusive goals in the twenty-first century. Thus, reformulating the public trust doctrine in New York by incorporating the historical public use test is not an antienvironment endeavor. Rather, it is an effort to make environmental ideals a reality in places where such ideals have previously gone unrealized. ${ }^{65}$

\section{Evolution Of The Public Trust Doctrine In NEW YORK}

New York's public trust doctrine is "inconsistent." 66 This flaw arises from common law development of the park/non-park use dichotomy. ${ }^{67}$ The inconsistency runs so deep that courts viewing the same public trust question often reach dramatically different results.

doctrine does not per se protect the environment, but rather protects natural resources for public use and benefit).

${ }^{63}$ See Charles A. Reich, The New Property, 73 YAle L.J. 733, 779 (1964) (arguing that property law is not a natural right, but rather "a construction designed to serve certain functions," such that "[t] he conditions that can be attached to receipt, ownership, and use depend not on where property came from, but on what job it should be expected to perform" and on "how it functions and how it should function"); see also supra notes 18-21 and accompanying text (arguing that the doctrine is a sociopolitical construct that evolves over time).

${ }^{64}$ See John Baden \& Tom Blood, Ecology and Enterprise: Toward the Private Management of Wildlife Resources, in ENTREPRENEURSHIP AND THE PRIVATIZING OF GOVERNMENT 67, 67-69 (Calvin A. Kent ed., 1987) (suggesting that government mismanagement of the environment results in "economic inefficiency compounded with environmental atrocities" and proposing that "'free market environmentalism," "based on private property rights, the rule of willing consent, and the market process," can produce optimal environmental benefits).

${ }^{65}$ See infra Part IV (discussing real-world applications of the reformulated public trust doctrine in New York City).

${ }^{66}$ Gresham, supra note 2, at 316.

${ }^{67}$ See Williams v. Gallatin, 128 N.E. 121, 122 (N.Y. 1920) (“[N]o objects, however worthy ..., which have no connection with park purposes, should be permitted to encroach upon [a park] without legislative authority plainly conferred ...."); Friends of Van Cortlandt Park v. City of New York, 750 N.E.2d 1050, 1053 (N.Y. 2001) ("In the 80 years since Williams, our courts have time and again reaffirmed the principle that parkland is impressed with a public trust, requiring legislative approval before it can be alienated or used for an extended period for non-park purposes." (footnote omitted)).

${ }^{68}$ See Gresham, supra note 2, at 281-82 (discussing dramatically different results reached by the New York Court of Appeals, which held that construction of water 
This doctrinal ambiguity poses a serious problem for the future of the doctrine in the state of New York. ${ }^{69}$ Courts apply the current doctrine willy-nilly according to their own normative sense of public policy and without any attention of ex ante considerations. The result is a doctrine so malleable as to lack meaning. As such, the time has come for a doctrinal shift away from the park/non-park use formulation and back towards the historical public trust doctrine, which requires that a public benefit potentially accrue before trust lands may be utilized by private parties. $^{70}$

The public trust doctrine in New York is a common law, not a statutory, doctrine. $^{71}$ New York courts "have a long tradition of extending public trust protections to municipal parks," "as well as tidal

treatment plant under parkland was a non-park use, and the federal district court, which, when reviewing identical facts, determined that the same plant provided an invaluable public benefit). Compare SFX Entm't, Inc. v. City of New York, 747 N.Y.S.2d 91, 92 (App. Div. 2002) (rejecting the lower court's finding that the concession agreement to construct an amphitheater on Randall's and Wards Islands violated the public trust doctrine), with SFX Entm't, Inc. v. City of New York, No. 124059/01, 2002 WL 1363372, at*8 (N.Y. Sup. Ct. June 13, 2002) (“[T] his particular concession violates the public trust doctrine because it authorizes substantial use of parkland for non-park purposes.").

${ }^{69}$ Gresham, supra note 2, at 281 ("Williams is simply not an adequate guide in the twenty-first century to what are proper park uses, as distinct from non-park uses requiring state enabling legislation.”).

${ }^{70}$ See supra Part I (discussing the origins of the public trust doctrine and its early formulation by the United States Supreme Court).

${ }^{71}$ See Gresham, supra note 2, at 269. ("Statutory controls and regulations have not been as important as the common law in New York park protection cases."). New York General City Law section 20.2 establishes that the rights of a city in its "parks, and all other public places, are hereby declared to be inalienable, except in the cases provided for by subdivision seven of this section.” N.Y. GEN. CITY LAW \$ 20.2 (McKinney 2003). The New York courts, however, have interpreted subdivision 7 of section 20.2 as not granting cities the power to discontinue or sell a park. See In re Cent. Parkway, 251 N.Y.S. 577, 580-81 (Sup. Ct. 1931) ("Under ... subdivision [7] a city may sell and convey only that which it may discontinue. Since it cannot discontinue parks, it cannot sell or convey the same."); Gewirtz v. City of Long Beach, 330 N.Y.S.2d 495, 510 (Sup. Ct. 1972) (finding that "the provisions of subdivision 7 do not eliminate the need for special legislative authority for alienation of a city's park lands" and citing In re Central Parkway). The New York City Charter contains language similar to the General City Law, and courts have interpreted it similarly. See N.Y. CITY CHARTER $§ 383$ (2003) ("The rights of the city in and to its ... parks ... are hereby declared to be inalienable; but upon the closing or discontinuance of any ... park ... the property may be sold or otherwise disposed of as may be provided by law ...."); Aldrich v. City of New York, 145 N.Y.S.2d 732, 743 (Sup. Ct. 1955) (holding that section 383 does not expressly grant "power to discontinue or close a park"). 
lands and navigable waters." ${ }^{72}$ The New York public trust doctrine as applied to municipal parkland requires "specific state legislative authorization for sale, alienations, or non-park uses of [trust] land." No such authorization, however, is necessary with respect to licenses and some leases of trust land granted by the executive branch to private individuals for a park use. ${ }^{74}$ Doctrinal confusion inevitably arises over whether a given transfer of municipal parkland to a private party via lease or license will result in a park use.

Three landmark cases decided by the New York Court of Appeals define the scope of, and illustrate the problems with, the public trust doctrine as currently applied to municipal parklands in that state. In Brooklyn Park Commissioners v. Armstrong, the Court of Appeals held that the City of New York could not sell or convey an interest in trust land without legislative approval. ${ }^{75}$ In Williams $v$. Gallatin, the Court of Appeals again expanded the public trust doctrine in New York, holding that municipalities could not enter into license or lease agreements with private parties for the purpose of putting public parkland to a non-park use without first obtaining legislative approval. ${ }^{76}$ Finally, in

${ }^{72}$ Gresham, supra note 2, at 268. It remains unclear, however, why New York courts applied the doctrine to protect municipal parks in the first place. Id. at 267-68.

${ }^{73}$ Id. at 268 (footnotes omitted); see also Williams v. Gallatin, 128 N.E. 121, 122 (N.Y. 1920) (holding that municipal parkland may not be used for a non-park purpose without authorization by the state legislature); Brooklyn Park Comm'rs v. Armstrong, 45 N.Y. 234, 243 (1871) (holding that municipal parkland may not be sold without legislative approval).

${ }^{74}$ Historically, the New York courts have deemed a lease of parkland an alienation of property, requiring legislative approval under Armstrong, 45 N.Y. at 243. In contrast, a license that was "consistent with park uses," that was "temporary and personal, avoiding the creation of any property interest," and that "contain[ed] a "terminable at will clause," did not require legislative approval. Gresham, supra note 2, at 304. More recent New York court decisions, however, have held "that not all leases of parkland without legislative sanction [are] invalid." Id. at 305; see, e.g., Port Chester Yacht Club, Inc. v. Vill. of Port Chester, 507 N.Y.S.2d 465, 467 (App. Div. 1986) (holding that the validity of a municipal lease of parkland "turns on the nature of the use rather than the nature of the user" and reasoning that the lease of a dock in a public park served a public purpose); see also Johnson v. Town of Brookhaven, 646 N.Y.S.2d 180, 181 (App. Div. 1996) (holding that a lease was improper under the public trust doctrine, but applying Port Chester Yacht Club rather than Armstrong).

7545 N.Y. 234, 243 (1871) ("[T] he city took the title to the lands . . for the public use as a park, and held it in trust for that purpose. . . . Receiving the title in trust for an especial public use, it could not convey without the sanction of the legislature ....").

${ }^{76} 128$ N.E. 121, 122 (N.Y. 1920) ("[N] o objects, however worthy . . ., which have no connection with park purposes, should be permitted to encroach upon [a park] without legislative authority plainly conferred ...."). Williams's vagueness is responsible for much of the doctrinal confusion in New York, as its park/non-park use rule permits tremendous judicial discretion and pivots on subjectivity. 
Friends of Van Cortlandt Park v. City of New York, the Court of Appeals unanimously held that the City's construction of a water treatment plant (WTP) under Van Cortlandt Park required legislative authorization because it would have disrupted public access to the public park for approximately five years. ${ }^{77}$ The court concluded that the disruption was a non-park use and therefore was impermissible under the public trust doctrine absent legislative approval. ${ }^{78}$

A closer look at the doctrine's evolution in New York state courts reveals a shift from a public use test to a park/non-park use test, resulting in increasing doctrinal confusion. Armstrong itself focused on the intersection between takings jurisprudence and the public trust doctrine, and is couched in public use language. In 1861, the City of Brooklyn exercised its taking power to acquire title to privately owned land for the purpose of establishing a public park. ${ }^{79}$ The land was "deemed to have been taken by the city for public use, as and for a public park." ${ }^{\$ 0}$ Subsequent to the taking, the City attempted, pursuant to an 1870 statute, to sell portions of the condemned land to private individuals. ${ }^{81}$ The defendant in the case refused to take title to one such parcel, arguing that the City lacked authority to transfer land taken for the public purpose of establishing a park. ${ }^{82}$

The opinion in Armstrong makes no mention of park use as the test for determining whether public parkland is being used in accordance with the public trust doctrine. Rather, the holding suggests that the doctrine, at its core, is connected to the notion of public use. The court, reasoning from within the takings context, stated:

Where the property is taken, the owner paid its true value, and the title vested in the public, it owns the whole property, and not merely the use; and, though the particular use may be abandoned [by legislative sanction], the right to the property remains. The property is still held in trust for the public by the authorities. ${ }^{83}$

\footnotetext{
77750 N.E.2d 1050, 1054 (N.Y. 2001) (“[L] egislative approval is required when there is a substantial intrusion on parkland for non-park purposes .... Here, the public will be deprived of valued park uses for at least five years, as plant construction proceeds.").

${ }^{78}$ Though the court deemed the disruption itself a non-park use, it did not reach the question of whether the operation of a WTP underneath Van Cortlandt Park would be a non-park use. Id.

${ }^{79}$ Armstrong, 45 N.Y. at 235.

${ }^{80} I d$. at 236.

${ }^{81} I d$. at $237-38$.

${ }^{82} I d$. at 238

${ }^{83} I d$. at 243.
} 
Certainly, one might interpret this passage consistently with the way the Williams court read it in $1920 .^{84}$ But the statement might also imply that what is vital to the public trust doctrine is not that it limits the use of parkland by private third parties to some particular type of park use, but rather that such land, owned by the public, must in some way be put to a public use for the public's benefit. That is, "though the particular use may be abandoned," the public's right to have the land used for its benefit-the right to have the land put to some public use-remains. Such a reading would seem to be consistent with the takings context in which the Armstrong court's statement was made. ${ }^{85}$

The Williams court's move away from a public use test towards a park/non-park use test in 1920 has confused the modern doctrine. In Van Cortlandt, for example, the City of New York was obligated to comply with a 1998 consent decree "requiring filtration and disinfection" of water flowing into the city from the Croton Watershed. ${ }^{86}$ The City proposed construction of a WTP underneath Van Cortlandt Park in the Bronx. ${ }^{87}$ The United States Federal District Court for the Eastern District of New York held that legislative approval of the project was unnecessary because there was "no transfer of an interest in land to another entity" and there would be "no diminution of parkland available for public use after the plant is built." ${ }^{, 8}$ On appeal, the Second Circuit certified the question, "[d]oes any aspect of the proposed [WTP] require state legislative approval," to the New York Court of Appeals. ${ }^{89}$ Answering this question in the affirmative, the Court of Appeals held that construction of the WTP was a non-park use because "the public will be deprived of valued park uses for at least five years, as plant construction proceeds."

${ }^{84}$ The Williams court apparently focused on the Armstrong court's previous assertion that the City took the property "for the public use as a park, and held it in trust for that purpose." Id. Thus, the particular public use protected by the trust doctrine in that instance was use as a park. Such a finding is undeniably consistent with Armstrong. My point, however, is the more subtle one-that, at its core, the public trust doctrine in New York incorporates the public use test, and that when courts move too far afield from the public use test, the public trust doctrine becomes unworkable.

${ }^{85}$ Though the meaning of "public use" in 2006 is no doubt different from its meaning in 1871, the notion is that in the two contexts-takings and public trust-the phrase should be interpreted consistently.

${ }^{86}$ Friends of Van Cortlandt Park v. City of New York, 750 N.E.2d 1050, 1051 (N.Y. 2001).

${ }^{87} I d$.

${ }^{88}$ United States v. City of New York, 96 F. Supp. 2d 195, 204 (E.D.N.Y. 2000).

${ }^{89}$ Van Cortlandt, 750 N.E.2d at 1053.

${ }^{90}$ Id. at 1054 . 
While the decision of the New York Court of Appeals is controlling, the inconsistency in doctrinal application is troubling. As one scholar has pointed out: "The history and controversy surrounding [Van Cortlandt] underscore that Williams is simply not an adequate guide in the twenty-first century to what are proper park uses ...."91 Further, it is hard to reconcile the New York court's categorical rejection of the project as a non-park use with the district court's decision that the WTP would "supply essential public services," notions of public use and public benefit.

Besides the three landmark cases discussed above, more recent holdings by the New York Supreme Court ${ }^{93}$ and Appellate Division ${ }^{94}$ in SFX Entertainment, Inc. v. City of New York similarly call into question the clarity and workability of the public trust doctrine as it applies to municipal parkland in New York. The Appellate Division partially reversed the Supreme Court in SFX II, and seemingly narrowed the doctrine's scope. That the Appellate Division did so without explanation or comment once again raises doubt as to the soundness of the park/non-park use doctrinal formulation.

The dispute in SFX I and SFX II arose out of an improperly conducted bidding process by the New York City Department of Parks and Recreation (Parks Department). The Parks Department, acting on the City's behalf, "circulated a Request for Expressions of Interest . . . seeking bids and proposals for development and management" of a proposed amphitheater to be constructed in Randall's and Wards Island Park. ${ }^{95}$ While intended as flexible guidelines, the Restoration and Development Plan (Plan) for the park envisioned a twenty-year license for a "'Plug \& Play festival entertainment facility,"” which would include "covered and open sloped-lawn seating"" and "would enhance the public's use, enjoyment, and recreation at the park" by ensuring the festival grounds would be "landscaped as parkland" and opened for "recreational activities during non-event days." ${ }^{96}$ Clear Channel, among the petitioners in the action, initially determined "the project was not suited to its business and did not submit a bid."

${ }^{91}$ Gresham, supra note 2, at 281.

${ }^{92}$ City of New York, 96 F. Supp. 2d at 202.

${ }^{93}$ SFX Entm't, Inc. v. City of New York (SFX I), No. 124059/01, 2002 WL 1363372, at $* 8$ (N.Y. Sup. Ct. June 13, 2002).

${ }^{94}$ SFX Entm't, Inc. v. City of New York (SFX II), 747 N.Y.S.2d 91 (App. Div. 2002).

${ }^{95}$ SFX I, 2002 WL 1363372, at *1.

${ }^{96} I d$. at *2 (quoting Verified Petition of SFX Entertainment, Inc. et al., Ex. C at 7).

${ }^{97} I d$. 
In fact, the only bid on the project came from Q-Prime and LGM Entertainment (bidding collectively as "Quincunx"), with whom the Parks Department began negotiating a long-term license. ${ }^{98}$

During negotiations between the Parks Department and Quincunx, the Plan changed drastically. First, Quincunx required a thirtyyear license. ${ }^{99}$ Second, and more significantly, Quincunx "proposed changes to the plan, including ... use of 19,200 permanent seats instead of the combination of fixed and lawn seats originally contemplated." ${ }^{100}$ Third, Quincunx limited the facility's operating schedule to April through October, deciding to close the facility to the public during the remaining five months of the year. ${ }^{101}$ The Parks Department accepted each of these changes without reopening the bidding process. ${ }^{102}$

The Supreme Court, New York County, struck down the agreement between the City and Quincunx on two grounds. First (and less important with respect to the analysis here), the court held that, "[b]ecause the Amphitheater Project varies substantially from what was envisioned in both the Plan and the Request [for proposals]," the project should have been reopened for bidding under applicable New York statutory law. ${ }^{103}$ Second, the Supreme Court held that the agreement "violates the public trust doctrine because it authorizes a substantial use of parkland for non-park purposes." ${ }^{104}$ The court applied Williams and Friends of Van Cortlandt Park, reasoning that the project agreement "entails use of over 9 acres of parkland for a private concert hall," which the public could enjoy only upon payment of "a sub-

98 Id.

99 Id. at $* 3$.

${ }^{100} \mathrm{Id}$.

$101 I d$. at $* 4$. As ultimately approved by the Parks Department, the license with Quincunx authorized the City "to hold a maximum of eight events a year on a nonholiday Monday, Tuesday, or Thursday." Id. at *5.

${ }^{102} I d$. at $* 3$. Even so, Clear Channel, upon learning of the changes, submitted a late proposal. Id. at *4. Its proposal "offered a 7,000-10,000 person reserved-seat theater," and provided the City

with a guaranteed base rent of at least $\$ 1.75$ million a year with a two-percent per year escalation, a guarantee that $\$ 56$ million would be due the City during the 25-year lease, and a commitment to dedicating one percent of its annual box office gross to the maintenance and refurbishment of playing fields on Randall's Island.

Id. (citing Verified Petition of SFX Entertainment, Inc. et al. at 8).

103 Id. at $* 7$.

104 Id. at $* 8$. 
stantial admission fee." ${ }^{105}$ Such a non-park use, according to the court, required legislative approval. ${ }^{106}$

While affirming the lower court's decision on the grounds that the "agreement was not 'consistent' with the proposal,"107 the Appellate Division "disagree[d] with [the] Supreme Court's determination that the award violated the public trust doctrine." 108 Without further explanation or comment, the Appellate Division held that the "proposed amphitheater [was] a permissible park use."109

What is really behind the Appellate Division's reversal in SFX II? Arguably, in its partial reversal the Appellate Division continues to use the park/non-park use language as a means to reach an end dictated by the historical public use test. ${ }^{110}$ In doing so, however, it has rendered the park/non-park use distinction virtually meaningless. That is, the desired end seems to be dictating the means of analysis. As such, the park/non-park language is merely a veneer to be draped over the court's decision vis-à-vis what constitutes a public use.

Under such circumstances, the time has come for a doctrinal shift back to the conceptual position in Armstrong. The New York courts should jettison the park/non-park use language and adopt a public use test in the context of the public trust doctrine. ${ }^{111}$ A public use test is superior to the park/non-park use formulation because it will facili-

105 Id. at $* 9$.

${ }^{106}$ See id. ("[T] he Legislature must be afforded the opportunity to consider whether this substantial use of parkland is in the best interests of New York citizens.").

${ }^{107}$ SFX II, 747 N.Y.S.2d at 92 (citing N.Y., N.Y., CODE tit. 12, §§ 1-12(w) (1) (effective July 1, 1991)).

${ }^{108} I d$.

109 Id.

${ }^{110}$ The amphitheater project fits the public use exception to the public trust doctrine because it would enhance public enjoyment of the park by increasing the scope of recreational activities available to park-goers, while simultaneously increasing tax revenue.

${ }^{111}$ The Appellate Division, in Port Chester Yacht Club v. Village of Port Chester, 507 N.Y.S.2d 465 (App. Div. 1986), appears to have made this switch back to a public use test. Ten years prior to the dispute in the case, the Village leased public parkland to the Yacht Club. Id. at 466. Subsequently, the Village sought to evict the Yacht Club under the theory that "the lease was void because the village had no authority to lease public park lands to a private club for private use." Id. The court denied the Village's motion for summary judgment, reasoning that a triable issue of material fact existed regarding whether the lease "serves public purposes." Id. at 467. The court's opinion does not discuss whether the Yacht Club was using the land for a park use, but rather couches its analysis in public use/purpose language. The key question, then, was whether the fact that "all residents of Port Chester, even nonmembers, may launch and recover their boats twice a year from the yacht club's launching ramps" was sufficient to constitute a public use. Id. at 466 . 
tate a return to the public trust doctrine's origins, permitting a marriage of financial entrepreneurship and environmental consciousness, thereby maximizing public benefit. Further, it will create some actual limits on judicial policymaking and will produce ex ante guidelines for contracting parties.

\section{BENEFITS OF DOCTRINAL REFORMULATION}

\section{A. Free-Market Environmentalism: \\ Privatization and Restoration of Forsaken Parks}

The New York City Department of Parks and Recreation is "the steward of nearly 28,700 acres of land, which make up 14 percent of New York City." ${ }^{\prime 12}$ Included among the 28,700 acres are approximately 12,000 acres of parkland that are "designated natural areas," 113 which the City, through the Parks Department, holds in public trust for the people of New York. This is an awesome responsibility. One, frankly, that in the wake of budget cuts over the past fifteen years, the City has been unable to meet. ${ }^{114}$

As a result, not all parks are equal. For example, one might wonder why the lawns visible from Central Park West are plush and green, while in a 3.3-acre municipal park in the Bronx, known as University Woods, "hypodermic needles, feces and used condoms litter[] the grounds." 115 Part of the answer is that, where public funding has proven grossly inadequate, a particular form of privatization, which can best be described as a hybrid of "contracting" and "private payment" privatization, has picked up the slack. ${ }^{116}$ New York City's "best

112 NeW YORK City DeP'T OF PARKs \& RECREATION, Biennial Report, in EIGHT SEASONS OF PROGRESS: 2002-2003, at 2, 2 (2003) [hereinafter Biennial Report], available at http://www.nycgovparks.org/sub_newsroom/biennial_report/biennial_02_03/images/ biennial2002_2003sm.pdf.

${ }^{113}$ Timothy Williams, Parks Even the Parks Dept. Won't Claim, N.Y. TIMES, July 6, 2005, at B1.

114 See Anemona Hartocollis, For Parks in a Tangle, A Plan To Tame, N.Y. TIMES, May $8,2005, \S 14$, at 1 ("Over the last 15 years, the Parks Department's full-time staff has been cut by 50 percent and its budget by at least 11 percent.”). Given the necessary budget cuts, it is no wonder that certain parks are (pardon the pun) going to seed.

${ }_{115}$ Williams, supra note 113, at B1.

${ }^{116}$ See Calvin A. Kent, Privatization of Public Functions: Promises and Problems, in ENTREPRENEURSHIP AND THE PRIVATIZING OF GOVERNMENT 3, 13-17 (Calvin A. Kent ed., 1987) (describing five forms of privatization, including the sale of government enterprises, contracting, private payment, competition, and public funding of private services). Contracting privatization "consists of contracting with the private sector to provide public services." Id. at 14 . Under private payment privatization, "government still 
maintained parks-Central Park, Bryant Park, and Prospect Park among them-are managed in part by private conservancies that raise money and hire workers independent of the Parks Department." 117 Central Park, in particular, "is the sine qua non of privatization," with all but $\$ 3.5$ million of its $\$ 25$ million annual operating budget coming from private sources. ${ }^{118}$

In contrast, what I will call "forsaken parks,"119 like University Woods in the Bronx and Highbridge Park in upper Manhattan, do not exactly stir the passions of wealthy corporations and philanthropists. ${ }^{120}$ Thus, this form of privatization will take us only so far. Further, some critics have suggested that the City, rather than investing "the money... saved through privatization" in needy parks, ${ }^{121}$ has chosen to abandon them. ${ }^{122}$ Even the Parks Department appears content to forsake these once-green spaces. ${ }^{123}$

The solution to this dilemma is an entirely different form of privatization, one that could become possible only if the New York public trust doctrine is reformulated. For where privatization fails, in the sense that individual and corporate philanthropists are unwilling to dedicate their private dollars to maintain such parks as parks, then perhaps private entrepreneurs can revitalize such forsaken green

provides the service," in this case maintaining green spaces such as Central Park and Bryant Park, but "the public pays the full cost of the service through user fees." $I d$. at 15. Nonprofit conservancies exhibit characteristics of these two forms of privatization, as they contract, in place of the Parks Department, with the private sector for park maintenance, while also paying huge user fees in the form of private contributions.

${ }^{117}$ Williams, supra note 113 , at B1.

${ }_{118}$ Hartocollis, supra note $114, \S 14$, at 1 .

${ }^{119}$ Such parks are forsaken in the sense that neither private philanthropy nor municipal government is willing to attempt to restore them.

${ }^{120}$ See, e.g., Biennial Report, supra note 112, at 16 (listing among the "Friends of Parks" conservancies such as The Battery Conservancy, Central Park Conservancy, Madison Square Park Conservancy, and Prospect Park Alliance, and recognizing corporate donors such as American Express, Goldman Sachs, Merck, Microsoft, the National Football League, Nike, and Verizon).

${ }^{121}$ Hartocollis, supra note $114, \S 14$, at 1 .

122 Williams, supra note 113, at B1 (reporting statements made by Parks Commissioner Adrian Benepe to the effect that the City plans to "[1] et nature take its course" with respect to such parks as University Woods, which the Commissioner described as "not a park").

${ }^{123}$ This Comment is in no way meant as an attack on the fine work undertaken by Parks Commissioner Adrian Benepe, his staff, and Parks Department employees. As Commissioner Benepe has stated, "[t] his is a big system and you can't address every little problem." Id. at B1. Rather, I mean only to suggest that where public management and privatization fail, perhaps a solution can be found in a reformulation of the public trust doctrine. 
spaces and the communities surrounding them. A park/non-park use rule, however, would hinder, if not entirely prevent, such development by preventing license or lease of such forsaken parks to private individuals without legislative approval. ${ }^{124}$ Thus, to restore these forsaken green spaces, it is first necessary to restore the public trust doctrine to its public use roots.

Such a reformulated public trust doctrine in New York would permit the City, through the Parks Department, to lease and license forsaken parkland to private parties for the dual purpose of economic and environmental development. Economic development need not be divorced from environmental goals, as illustrated by the construction of fee-based recreational spaces side by side with environmentally friendly commercial spaces. ${ }^{125}$ There is no reason why private entrepreneurs cannot construct entrepreneurial spaces and park spaces under the theory of "free-market environmentalism."

The Thoreau Institute defines free-market environmentalism as follows:

Like all environmentalists, free-market environmentalists believe that we face serious environmental problems, including pollution, habitat destruction, toxics, and endangered species. Unlike some environmentalists, free-market environmentalists believe that decentralized tools such as user fees, incentives, and markets will solve those problems better than centralized tools such as subsidies, bureaucracy, and regulation. ${ }^{12}$

Free-market environmentalism rests on the assumption that the environment is a valuable asset with market value derived from its recreational uses. ${ }^{127}$ The point is that park recreation has a market value:

${ }^{124}$ While it is true that legislative approval might be procured for such arguably non-park uses, there are few certainties in the legislative process. Indeed, the only certainties are that such a process is costly and full of political pitfalls. Years may pass before legislative approval is received, if ever. The unfortunate fact remains that forsaken parks are not top political priorities for state senators and assemblypersons.

${ }^{125}$ Commercial spaces need not be limited to retail venues, but rather might also include privately run indoor concert halls, minor league baseball stadiums, aquariums, restaurants, hotels, and museums. Some of these uses are arguably park uses, but all of them can create public benefit in the forms of education and entertainment.

${ }^{126}$ The Thoreau Institute, FAQs About Free-Market Environmentalism, http:// www.ti.org/faqs.html (last visited Oct. 22, 2006).

${ }^{127}$ See id. (suggesting that the market value of recreation in United States national forests approaches $\$ 6.6$ billion annually); see also J. Bishop Grewell, All Play and No Pay: The Adverse Effects of Welfare Recreation, in GOVERNMENT VS. ENVIRONMENT 11 (Donald R. Lear \& Roger E. Meiners eds., 2002), available at http://www.perc.org/pdf/ govenv_ch9.pdf (arguing that "parks already are commercialized" and asserting that "[r] ecreation is commercial activity" aligned with the tourism industry). 
people are willing to pay for it. Therefore, private entrepreneurs should be willing to operate parks in exchange for licenses and the right to collect user fees. ${ }^{128}$ As such, development of forsaken parkland as a hybrid commercial-recreational park might produce sufficient financial incentives to private entrepreneurs, while simultaneously revitalizing parkland and potentially, through job creation, the surrounding neighborhoods. ${ }^{129}$

\section{B. Increasing Public Benefit from Maintained Parks}

A reformulated public trust doctrine will also permit the realization of optimal public benefit from maintained parks. ${ }^{130}$ As discussed above, ${ }^{131}$ the decision in SFX II to permit construction of an amphitheater in Randall's and Wards Island Park, so long as the contract was properly rebid, is best explained under a public use formulation of the public trust doctrine. The amphitheater creates optimal public

${ }^{128}$ While user fees seem antithetical to the notion of a public park, they are absolutely necessary to conserve parkland where a public funding gap exists with respect to particular parks. The demand for free access to public parks, what Grewell calls "welfare recreation," creates a tremendous strain on park resources and the environment via overuse and abuse of parkland. Grewell, supra note 127, at 2 . Thus, welfare recreation is not consistent with conservationist goals. Rather, privatization and collection of user fees will help preserve parkland by "link[ing] costs with revenues," $i d$. , and removing park management from the political realm. See id. at 6 (implying that Congress diverts funds budgeted for improvement and repair of park infrastructure to expensive pork projects such as "gold-plated outhouses").

${ }^{129}$ Seattle's Ravenna Park was once such a model of park privatization. At the turn of the twentieth century, "it was a privately owned park that contained magnificent Douglas firs," and which a husband and wife "had developed ... into a family recreation area that brought in thousands of people a day." Richard Stroup, Environmentalism, Free-Market, in LIBRARY OF ECON. \& LIBERTY, THE CONCISE ENCYCLOPEDIA OF ECONOMICS (David R. Henderson ed., 2002) http://www.econlib.org/library/Enc/ EnvironmentalismFreeMarket.html. The government, wishing to preserve the park after its proprietors' deaths, purchased it after condemnation proceedings had occurred. Id. Under public control, however, the park deteriorated and became "an ugly, dangerous hangout for drug users" by 1972. Id. The Ravenna Park example is, of course, temporally inverted for purposes of the current analysis, but the point is salient: private entrepreneurs can do a better job than government in managing parkland. Cf. Alexander Orwin, The Privatization of Water and Wastewater Utilities: An International Survey, ENV'T PROBE, Aug. 1999, http://www.environmentprobe.org/ enviroprobe/pubs/ev542.html (surveying the benefits and the pitfalls of privatization of water and sewage utilities throughout the world and finding that private companies can better solve the intractable problems facing government-owned utilities, such as inadequate infrastructure, shortage of funds, and politicized decision making).

${ }^{130}$ By "maintained parks" I mean parks that are sufficiently funded, but that are not being optimally used for the public benefit.

${ }^{131}$ See supra Part III (summarizing the disagreement among New York cases). 
benefit in the form of recreational enjoyment, employment opportunities, and increased tax revenue. As long as the public benefits of development outweigh the public benefit associated with permitting the land to remain as open, undeveloped space, the courts should not void the license. Thus, the Appellate Division's decision, though unelaborated, appears correct.

Van Cortlandt, however, appears wrongly decided under the reformulated doctrine, because the public benefit from building a WTP under the park should have been sufficient to permit the City of New York to move forward with the project. Rather than bar such projects, the public trust doctrine, as properly understood in light of the evolution of the public use test, actually compels such performance in the public interest. While building the WTP would temporarily close certain sections of the park, this negative short-term outcome simply does not outweigh the long-term public benefit derived from safe and healthy drinking water. If the City had proposed permanently altering the park, then the balancing might be different, but permanent alterations, if any, appeared to be minor in this case. ${ }^{132}$

\section{Incidental Benefits of a Reformulated Public Trust Doctrine}

Additionally, a reformulated public trust doctrine in New York will produce three incidental benefits. First, reformulation will match the doctrine to reality. Cases like $S F X$, in which the courts seem to be reaching for an explanation of why some proposed project is permissible under the public trust doctrine, are eminently more explicable under a public use formulation of the doctrine. Second, because the reformulated rule produces doctrinal clarity, contracting parties will better be able to ascertain ex ante whether their proposed transactions will pass judicial muster.

Finally, a public use reformulation will limit, though not eliminate, judicial policymaking. As discussed above, the definition of park/non-park use is vague and often compels the Court of Appeals and Appellate Division to make determinations based on their own

${ }^{132}$ See Friends of Van Cortlandt Park v. City of New York, 750 N.E.2d 1050, 1052 (N.Y. 2001) (recounting that WTP construction would require demolition of certain park structures, which would later be restored, and noting that vents and air intake louvers would permanently extend above ground). 
policy preferences. ${ }^{133}$ Yet these courts should not make policy; elected officials should. ${ }^{134}$ A reformulated public trust doctrine will limit judicial discretion for three reasons. First, courts will be more deferential to the public use test because it has a constitutional grounding in the Fifth Amendment. Second, state courts are more likely to tread lightly where they know the contemporary U.S. Supreme Court has weighed in on the meaning and limits of the public use test. Third, while some room for debate exists regarding whether a particular use is a public use, the U.S. Supreme Court has firmly established categories of public uses. Thus, while the public use doctrine itself may be less than perfectly clear, its contours are more clearly drawn than those of the park/non-park use test New York courts currently employ. As such, the public use test is not open to the same degree of ad hoc categorization to which the park/non-park test is susceptible.

\section{CONCLUSION}

The public trust doctrine has undergone major revisions since its initial enunciation in Illinois Central Railroad in 1892. Indeed, the doctrine continues to evolve today. As currently constituted with respect to parkland in New York State, however, the doctrine has become so malleable that it lacks meaning. Thus, the next step in the doctrine's evolution in New York should be a return to its historical public use roots. Reincorporation of the public use test, as clearly enunciated in cases like Morris and Kelo, will not only clarify the public trust doctrine, but also provide for greater private entrepreneurship opportunities, focused on producing optimal public benefit and restoring green spaces. Restoration of forsaken parks and more permissive private participation in producing optimal public benefits in well-maintained parks are but two immediate benefits of doctrinal reformulation. No doubt additional factual contexts will reveal other public benefits in time, both in New York and in other states where similar problems exist.

133 See supra notes 68-69 and accompanying text ("Williams is simply not an adequate guide in the twenty-first century to what are proper park uses, as distinct from non-park uses requiring state enabling legislation.").

${ }^{34}$ While Supreme Court and County Court judges are elected in New York State, Court of Appeals and Appellate Division judges are appointed by the Governor, based on merit. Am. Judicature Soc'y, Judicial Selection in the States, New York: Current Methods of Judicial Selection, http://www.ajs.org/js/NY_methods.htm (last visited Oct. 22, 2006). As evidenced by the cases cited in Part III, supra, it is the appointed appellate judges who are shaping the public trust doctrine in New York. 